\title{
A Nationwide Community Survey of Prevalence of Circumcision among Egyptian Children and Risk of Hepatitis B Viral Infection
}

Iman I. Salama ${ }^{1}$, Samia M. Sami ${ }^{2}$, Somaia I. Salama ${ }^{1}$, Dalia M. Elmosalami ${ }^{1}$, Rehan M. Saleh ${ }^{1}$, Zeinab N. Said ${ }^{3}$ Fatma A. Shaaban ${ }^{2}$, Aida M. Abdelmohsen ${ }^{1}$, Thanaa Mahmoud Rabah ${ }^{1}$, Ghada A. Abdel-Latif ${ }^{1}$, Walaa A. Fouad ${ }^{1}$, Amira Mohsen

${ }^{1}$ Department of Community Medicine, National Research Centre, Cairo, Egypt; ${ }^{2}$ Department of Child Health, National Research Centre, Cairo, Egypt; ${ }^{3}$ Department of Microbiology and Immunology, Faculty of Medicine (for Girls), Al-Azhar University, Cairo, Egypt

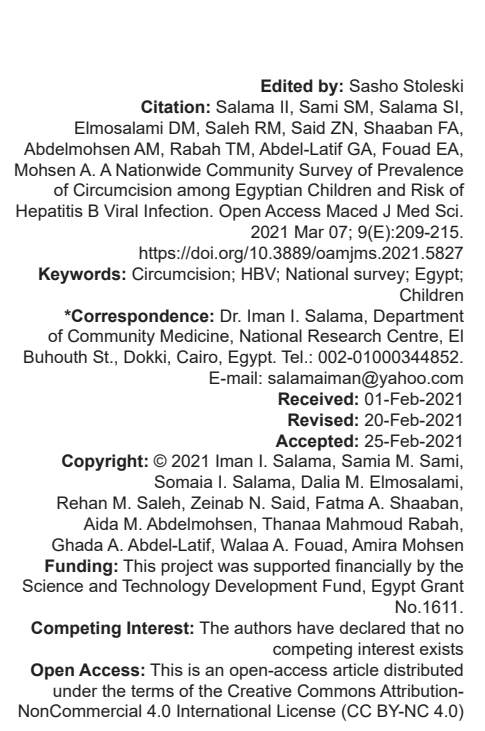

\begin{abstract}
AIM: To assess prevalence and risk factors of circumcision among Egyptian children and to assess the risk factors for HBV infection among them.

METHODS: A nationwide community survey was carried out on 3306 children aged from 9 months to 16 years, of both genders. Data were collected during face to face interviews with the parents and children. All studied children had received HBV vaccination during infancy. Total anti-HBc and HBsAg were assessed by ELISA followed by HBV DNA detection for positive cases by Real-time PCR.

RESULTS: Prevalence of circumcision was $92.3 \%$ among boys and $29.7 \%$ among girls. The percentage of circumcised girls was significantly higher in rural (38.1\%) than urban $(21.1 \%), \mathrm{P}<0.01$ and more in Upper $(42.2 \%)$ and Lower Egypt $(27.6 \%)$ compared to Cairo, the Capital $(14.1 \%), \mathrm{P}<0.001$. Boys showed significantly higher prevalence of circumcision in urban $(94.1 \%)$ compared to rural areas $(90.1 \%), \mathrm{P}<0.001$. The prevalence of HBV breakthrough infection, detected by HBV-DNA, was 14/3306 (0.42\%). No significant differences between circumcised and non-circumcised boys and girls regarding the different serological tests of HBV infection, $P>0.05$. Using logistic regression analysis, mothers' illiteracy or having primary and preparatory education carried six times and 2 times risk respectively of having their daughter circumcised compared to higher education, $P<0.01$. Living in Upper or Lower Egypt carried three times and 1.5 times risk respectively of having circumcised girl compared to the Capital, $P<0.001$. HBV infection among family was the independent risk factor for HBV infection among girls and boys, in addition to frequent medical injection among boys, $P<0.05$.
\end{abstract}

CONCLUSION: Circumcision among girls is still a problem especially in Upper Egypt and in rural areas. Child circumcision in Egypt seems not to play a role in HBV infection and intra-familial HBV transmission and frequent medical injection are the most important risk factors.

\section{Introduction}

Male circumcision (MC) is one of the most common and oldest surgical procedures worldwide and is undertaken for many reasons: religious, cultural, social, medical and ethnicity. The most common determinant of circumcision globally is religion (Islam and Jews) and ethnic identity. However, it has been performed for nonreligious reasons for many thousands of years in subSaharan Africa, and in many ethnic groups around the world [1], [2], [3].

In contrast to $\mathrm{MC}$, female circumcision or female genital mutilation (FGM) has no known health benefits and is not performed for medical reasons. It is performed for females in certain countries for cultural considerations [4] and inhibiting sexual feelings [5]. FGM is now firmly on the global development agenda, most prominently through its inclusion in Sustainable
Development Goal (SDG) target 5.3, which aims to eliminate this practice by 2030 [6].

In low-income countries, the instruments for circumcision, used by physicians, nurses, and barbers in urban and rural areas, might not be sterilized properly after each use or just immersed into an antiseptic liquid. Although circumcision might be performed by trained surgeons, yet $7 \%$ of cases were unsafe [7]. Thus, children and youth might be exposed to blood-borne pathogens (hepatitis B virus [HBV], HCV, and HIV) through circumcision where traditional and medical circumcision are often performed un-hygienically [8], [9] .

HBV infection is a global public health challenge, with an estimated 257 million people chronically hepatitis B surface antigen ( $\mathrm{HBsAg}$ ) positive. According to the $2017 \mathrm{WHO}$ global hepatitis report [10], the highest prevalence of HBsAg-positive individuals was in the Western Pacific region (with prevalence estimated as 6.2\%) and African region 
(prevalence estimate 6.1\%), which together accounted for $68 \%$ of the global burden. In 2015, hepatitis B resulted in an estimated 887,000 deaths, mostly from the complications of the disease, for example, cirrhosis and hepatocellular carcinoma [11].

HBV commonly spread by mother to infant through vertical transmission during birth, circumcision, transfusion of blood products, injection of intravenous drug, sexual contacts, sharing unsterilized syringes and needles, scarifications/tattooing, institutional care, and close intimate care with carriers [11], [12], [13]. The risk of developing chronic HBV infection commonly defined (as being positive for HBsAg for greater than 6 months) is inversely proportional to the age of acquisition of the infection; the risk ranges between $80-90 \%$ after newborn infection, 20-50\% among children under 6 years, and less than 5\% among adults [12]

There are few publications about the association between circumcision and acquisition of viral hepatitis B markers either in Egypt or in Middle East countries. Hence, the aim of the present study was to determine the prevalence and risk factors of circumcision among the Egyptian children and to assess the risk factors for HBV among them.

\section{Materials and Methods}

This study is part of a community based national project conducted in six governorates representing Egypt using a multi-stage cluster sampling. The six governorates were selected from different geographical regions of Egypt. The study sample included 3306 Egyptian children (1596 boys and 1710 girls) aged from 9 months to 16 years and retrieved from urban and rural areas of the six selected governorates. All children were fully vaccinated by the three compulsory HBV vaccine doses. The sample frame for the survey was based on the population census of Egypt, 2006. Details of sample size and sampling design of the project are reported in previous work [14].

The ethical committee approvals were obtained from the Ministry of Health and Population, National Research Centre and Ministry of Education. After signing the written consent, face to face interview was conducted with the child's parents or caretakers. In addition, children above 10 years were interviewed after taking their verbal ascent. Child personal data, demographic and socioeconomic variables, history of circumcision, current and medical history, and family history of HBV infection were collected through a pretested questionnaire. Socioeconomic status (SES) was determined according to the following items: education of parents, maternal working status, water source, sewage disposable, electricity, and family income [15].

\section{Laboratory analysis}

A blood sample (3-5 mL) was withdrawn from each child aseptically and serum was aliquoted into two labeled sterile cryotubes and stored at $-20^{\circ} \mathrm{C}$. Detection of HBV markers was performed in the Virology Lab Microbiology and Immunology Department-Faculty of Medicine (for girls), Al-Azhar University, Cairo. Serum total anti-HBc and $\mathrm{HBsAg}$ were assessed using commercially available enzyme linked immunoassays (DiaSorin-Italy) according to the manufacturer instructions. Repeatedly positive samples for either anti-HBc or HBsAg were subjected to quantification of HBV DNA by real-time PCR using automated system. Viral DNA was extracted from serum samples using QIAxtractor ${ }^{\circledR}$, and $\mathrm{VX}$ kit as recommended by the manufacturer (QIAGEN, Germany). Details of the HBVDNA analyses are available in previous work [16].

\section{Statistical analysis}

Data entry and statistical analysis were done using SPSS software program version 18.0. Qualitative data were presented by numbers and percentages. Bivariate analysis was applied using Chi-square test $\left(\chi^{2}\right)$ for qualitative variables that were presented by numbers and percentages and odds ratio and 95\% confidence interval $(\mathrm{Cl})$ were computed to assess the degree of association. Three multivariate logistic backward-Wald analysis were carried out to predict risk factors significantly associated with the practice of girl circumcision and two models for predicting the risk HBV infection among both boys and girls. $p<0.05$ was considered statistically significant and $p<0.01$ was considered statistically highly significant.

\section{Results}

The prevalence of circumcision was significantly higher among boys in urban $(94.1 \%)$ compared to rural areas $(90.1 \%), p<0.001$ and the majority of studied boys were circumcised by doctors $(89.9 \%)$ and at private clinics (57.2\%). The percentage of circumcised boys by doctors was higher in urban than in rural regions and those circumcised by paramedical persons was higher in rural than urban districts, $p<0.001$. Among girls, the percentage of circumcision was significantly higher among rural girls $(38.1 \%)$ than those living in urban region $(21.1 \%), p<0.001$. Doctors were the main person who performed girl circumcision in both urban $(73.7 \%)$ and rural regions (59.0\%). The percent of circumcised girls by midwives/dayas was higher in rural versus urban region $(27.1 \%$ vs. $7.3 \%), p<0.001$. As regards the place of performing circumcision, the main place in rural regions was at home $(70.8 \%)$ while it was private clinics in urban regions $(61.5 \%), p<0.001$ (Table 1). 
Table 1: Practices of circumcision among boys and girls according to residence

\begin{tabular}{|c|c|c|c|c|}
\hline Circumcision practices & Total, n (\%) & Rural, n (\%) & Urban, n (\%) & OR $(95 \% \mathrm{Cl})$ \\
\hline \multicolumn{5}{|l|}{ Among 1596 boys } \\
\hline \multicolumn{5}{|l|}{ Circumcised boys } \\
\hline No & $123(7.7)$ & $72(9.9)$ & $51(5.9)$ & \multirow[t]{3}{*}{$2.3(1.8-2.8)^{\star \star}$} \\
\hline Yes & $1473(92.3)$ & $657(90.1)$ & $816(94.1)$ & \\
\hline $\begin{array}{l}\text { Who circumcised the } \\
\text { boys }\end{array}$ & $\mathrm{n}=1436^{\#}$ & $\mathrm{n}=656^{\#}$ & $\mathrm{n}=780^{\#}$ & \\
\hline Doctor & $1291(89.9)$ & $579(88.2)$ & $712(91.3)$ & \multirow[t]{6}{*}{$p<0.001$} \\
\hline Nurse & $20(1.4)$ & $9(1.4)$ & $11(1.4)$ & \\
\hline Midwife/daya & $8(0.6)$ & $5(0.8)$ & $3(0.4)$ & \\
\hline Paramedical & $75(5.2)$ & $52(8.0)$ & $23(2.9)$ & \\
\hline Do not know & $42(2.9)$ & $11(1.7)$ & $31(4.0)$ & \\
\hline Place of circumcision & $n=1410^{*}$ & $n=657$ & $n=753^{\prime \prime}$ & \\
\hline Private clinic & $806(57.2)$ & $353(53.8)$ & $453(60.2)$ & \multirow[t]{3}{*}{$p<0.001$} \\
\hline Home & $216(15.3)$ & $147(22.4)$ & $69(9.1)$ & \\
\hline Health care facilities & $388(27.5)$ & $157(23.9)$ & $231(30.7)$ & \\
\hline \multirow{2}{*}{\multicolumn{5}{|c|}{$\begin{array}{l}\text { Among } 1710 \text { girls } \\
\text { Circumcised girls }\end{array}$}} \\
\hline & & & & \\
\hline No & $1202(70.3)$ & $534(61.9)$ & $668(78.9)$ & \multirow[t]{2}{*}{$2.3(1.9-2.9)^{\star \star}$} \\
\hline Yes & $508(29.7)$ & $329(38.1)$ & $179(21.1)$ & \\
\hline \multicolumn{5}{|c|}{ Who circumcised the girls } \\
\hline Doctor & $326(64.2)$ & $194(59.0)$ & $132(73.7)$ & \multirow[t]{5}{*}{$p<0.001$} \\
\hline Nurse & $46(9.0)$ & $26(7.9)$ & $20(11.2)$ & \\
\hline Midwife/daya & $102(20.1)$ & $89(27.1)$ & $13(7.3)$ & \\
\hline Paramedical & $14(2.8)$ & $9(2.7)$ & $5(2.8)$ & \\
\hline Do not know & $20(3.9)$ & $11(3.3)$ & $9(5.0)$ & \\
\hline \multicolumn{5}{|l|}{ Place of circumcision } \\
\hline Private clinic & $206(40.6)$ & $96(29.2)$ & $110(61.5)$ & \multirow[t]{2}{*}{$4.0(2.7-5.9)^{\star \star}$} \\
\hline Home & $302(59.4)$ & $233(70.8)$ & $69(38.5)$ & \\
\hline
\end{tabular}

The prevalence of girl circumcision was significantly increased by age being $2.5 \%$ among girls aged $<5$ years, while it reached $50.5 \%$ among girls in the age group $\geq 10$ years. The percentage of circumcised females was significantly $(p<0.001)$ higher in rural $(38.1 \%)$ than urban areas $(21.1 \%)$. It was significantly practiced 2 and 3 times more in Lower and Upper Egypt compared to Capital, $(p<0.001)$. The practice of circumcision among girls is inversely proportional with their SES, parents' education and parent's occupation, $p<0.05$ (Table 2).

Regarding HBV infection, 13 children were positive for anti-HBc $(0.393 \%), 4$ children were positive for HBsAg $(0.121 \%), 3$ children were positive for both markers $(0.091 \%)$, and all the 14 children were positive for HBV-DNA $(0.423 \%)$. Among circumcised children, all HBV markers were detected among children circumcised by doctors mainly in health care clinic. Table 3 shows no significant differences between circumcised and non-circumcised children as regards the different serological tests of HBV. After stratification of the results according to gender, non-circumcised boys experienced insignificant higher percentages of positive anti-HBc and HBV-DNA compared to circumcised boys $(p=0.051)$. There were no significant differences in serological tests between circumcised and non-circumcised among girls, different age groups or residence.

Table 4 presents the results of three logistic regression analyses, one for predicting the risk factors for girl circumcision and the other two models for predicting the risk factors associated with $\mathrm{HBV}$ infection among both girls and boys. The first model revealed that maternal lower education and living in Upper and Lower Egypt were the significant predicting factors for girl circumcision, $p<0.01$. As regards the predicting

Table 2: Some sociodemographic risk factors for circumcision among the studied girls

\begin{tabular}{|c|c|c|c|c|}
\hline Variables & Total girls $(n=1710)(n)$ & Circumcised $(n=508 ; 29.7 \%), n(\%)$ & Non-circumcised $(\mathrm{n}=1202 ; 70.3 \%), \mathrm{n}(\%)$ & $\mathrm{OR}(95 \% \mathrm{Cl})$ \\
\hline \multicolumn{5}{|l|}{ Age groups (years) } \\
\hline$<5$ & 480 & $12(2.5)$ & $468(97.5)$ & 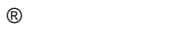 \\
\hline $5 \leq 10$ & 287 & $20(7.0)$ & $267(93.0)$ & $2.9(1.4-6.1)^{\star \star}$ \\
\hline$\geq 10$ & 943 & $476(50.5)$ & 467 (49.5) & $39.8(22.1-71.5)^{\star \star}$ \\
\hline \multicolumn{5}{|l|}{ Place of residence } \\
\hline Cairo & 348 & $49(14.1)$ & $299(85.9)$ & ® \\
\hline Lower Egypt & 791 & $218(27.6)$ & $573(72.4)$ & $2.3(1.7-3.3)^{\star \star}$ \\
\hline Upper Egypt & 571 & $241(42.2)$ & $330(57.8)$ & $4.5(3.2-6.3)^{\star \star}$ \\
\hline \multicolumn{5}{|l|}{ Urban-rural residence } \\
\hline Rural & 863 & $329(38.1)$ & $534(61.9)$ & $2.3(1.9-2.9)^{\star *}$ \\
\hline Urban & 847 & $179(21.1)$ & $668(78.9)$ & (8) \\
\hline \multicolumn{5}{|l|}{ Socioeconomic level } \\
\hline Very low & 504 & $207(41.1)$ & $297(58.9)$ & $3.1(2.3-4.2)^{\star *}$ \\
\hline Low & 328 & $125(38.1)$ & $203(61.9)$ & $2.7(2.0-3.8)^{\star *}$ \\
\hline Middle & 439 & $95(21.6)$ & $344(78.4)$ & $1.2(0.9-1.7)$ \\
\hline High & 439 & 81 (18.5) & $358(81.5)$ & (B) \\
\hline \multicolumn{5}{|l|}{ Mother education } \\
\hline Illiterate & 474 & $211(44.5)$ & $263(55.6)$ & $6.5(4.4-9.7)^{\star \star}$ \\
\hline Read and write & 81 & $32(39.5)$ & $49(61.2)$ & $5.3(3.0-9.3)^{\star \star}$ \\
\hline Primary & 75 & $32(42.7)$ & $43(57.3)$ & $6.0(3.4-10.7)^{\star *}$ \\
\hline Preparatory & 102 & $35(34.3)$ & $67(65.7)$ & $4.2(2.5-7.3)^{\star \star}$ \\
\hline Secondary or diploma & 669 & $164(24.5)$ & $505(75.5)$ & $2.6(1.8-3.9)^{\star \star}$ \\
\hline University or higher & 309 & $34(11.0)$ & $275(89.0)$ & (B) \\
\hline \multicolumn{5}{|l|}{ Father education } \\
\hline Illiterate & 308 & $110(35.7)$ & $198(64.3)$ & $2.2(1.6-3.1)^{\star *}$ \\
\hline Read and write & 164 & 65 (39.6) & $99(60.4)$ & $2.6(1.7-3.8)^{\star \star}$ \\
\hline Primary & 93 & 37 (39.8) & $56(60.2)$ & $2.6(1.6-4.2)^{\star \star}$ \\
\hline Preparatory & 103 & 46 (44.7) & 57 (55.3) & $3.2(2.0-5.0)^{\star *}$ \\
\hline Secondary or diploma & 642 & $168(26.2)$ & $474(73.8)$ & $1.4(1.0-1.9)$ \\
\hline University or higher & 399 & $81(20.3)$ & 318 (79.7) & (®) \\
\hline \multicolumn{5}{|l|}{ Father occupation } \\
\hline Jobless & 132 & $54(40.9)$ & $78(59.1)$ & $2.7(1.6-4.4)^{\star \star}$ \\
\hline Manual worker & 768 & $227(29.6)$ & $541(70.4)$ & $1.6(1.1-2.4)^{\star}$ \\
\hline Employee (government/private) & 625 & 189 (30.2) & $436(69.8)$ & $1.7(1.1-2.5)^{\star}$ \\
\hline $\begin{array}{l}\text { Professional jobs (doctor/engineer/lawyers, } \\
\text { etc.) }\end{array}$ & 185 & $38(20.5)$ & $147(79.5)$ & ® \\
\hline \multicolumn{5}{|l|}{ Mother occupation } \\
\hline Housewife & 1260 & $400(31.7)$ & $860(68.3)$ & $2.3(1.3-4.0)^{\star \star}$ \\
\hline Manual worker & 62 & $19(30.6)$ & $43(69.4)$ & $2.2(1.0-4.7)^{\star}$ \\
\hline Employee (government/private) & 300 & $75(25.0)$ & $225(75.0)$ & $1.6(0.9-3.0)$ \\
\hline $\begin{array}{l}\text { Professional jobs (doctor/engineer/lawyers, } \\
\text { etc.) }\end{array}$ & 89 & $15(16.9)$ & $74(83.1)$ & ${ }^{\circledR}$ \\
\hline
\end{tabular}


Table 3: Association between circumcision and hepatitis B markers among the studied children in relation to age, gender, and urban-rural residence

\begin{tabular}{|c|c|c|c|c|}
\hline \multirow[t]{2}{*}{ Variables } & \multirow[t]{2}{*}{ Circumcision status } & \multicolumn{3}{|c|}{ Hepatitis B markers } \\
\hline & & $\begin{array}{l}\text { Positive for } \\
\text { HBsAg, n (\%) }\end{array}$ & $\begin{array}{l}\text { Positive for } \\
\text { anti-HBc, n (\%) }\end{array}$ & $\begin{array}{l}\text { Positive for } \\
\text { HBV-DNA, n (\%) }\end{array}$ \\
\hline \multirow[t]{3}{*}{ Total children } & Circumcised $(n=1981)$ & $2(0.10)$ & $6(0.30)$ & $6(0.30)$ \\
\hline & $\begin{array}{l}\text { Not } \\
\text { circumcised }(n=1325)\end{array}$ & $2(0.15)$ & $7(0.53)$ & $8(0.60)$ \\
\hline & $\mathrm{p}$ & 0.995 & 0.397 & 0.274 \\
\hline \multicolumn{5}{|l|}{ Gender } \\
\hline \multirow[t]{3}{*}{ Boys } & Circumcised $(n=1473)$ & $1(0.07)$ & $3(0.20)$ & $3(0.20)$ \\
\hline & $\begin{array}{l}\text { Not } \\
\text { circumcised }(n=123)\end{array}$ & $1(0.81)$ & $2(1.63)$ & $2(1.63)$ \\
\hline & $\mathrm{P}$ & 0.148 & 0.051 & 0.051 \\
\hline \multirow[t]{3}{*}{ Girls } & Circumcised $(n=508)$ & $1(0.20)$ & $3(0.59)$ & $3(0.59)$ \\
\hline & $\begin{array}{l}\text { Not } \\
\text { circumcised }(n=1202)\end{array}$ & $1(0.08)$ & $5(0.42)$ & $6(0.50)$ \\
\hline & $\mathrm{p}$ & 0.506 & 0.701 & 0.730 \\
\hline \multicolumn{5}{|c|}{ Age groups (years) } \\
\hline \multirow[t]{3}{*}{$<5$} & Circumcised $(n=485)$ & $0(0.00)$ & $1(0.21)$ & $1(0.21)$ \\
\hline & $\begin{array}{l}\text { Not } \\
\text { circumcised }(n=549)\end{array}$ & $0(0.00)$ & $0(0.00)$ & $0(0.00)$ \\
\hline & $\mathrm{p}$ & - & 0.469 & 0.469 \\
\hline \multirow[t]{3}{*}{$5 \leq 10$} & Circumcised $(n=298)$ & $0(0.00)$ & $0(0.00)$ & $0(0.00)$ \\
\hline & $\begin{array}{l}\text { Not } \\
\text { circumcised }(n=283)\end{array}$ & $1(0.35)$ & $2(0.71)$ & $3(1.06)$ \\
\hline & $\mathrm{p}$ & 0.487 & 0.237 & 0.115 \\
\hline \multirow[t]{2}{*}{$\geq 10$} & $\begin{array}{l}\text { Circumcised }(n=1198) \\
\text { Not } \\
\text { circumcised }(n=493)\end{array}$ & $\begin{array}{l}1(0.16) \\
1(0.33)\end{array}$ & $\begin{array}{l}1(0.16) \\
5(1.63)\end{array}$ & $\begin{array}{l}5(0.42) \\
5(1.63)\end{array}$ \\
\hline & \multicolumn{4}{|c|}{ Residence } \\
\hline \multirow[t]{3}{*}{ Urban } & Circumcised $(n=995)$ & $1(0.10)$ & $3(0.30)$ & $3(0.30)$ \\
\hline & $\begin{array}{l}\text { Not } \\
\text { circumcised }(n=719)\end{array}$ & $2(0.28)$ & $3(0.42)$ & $4(0.56)$ \\
\hline & $\mathrm{p}$ & 0.576 & 0.700 & 0.462 \\
\hline \multirow[t]{3}{*}{ Rural } & Circumcised $(n=986)$ & $1(0.10)$ & $3(0.30)$ & $3(0.30)$ \\
\hline & $\begin{array}{l}\text { Not } \\
\text { circumcised }(n=606)\end{array}$ & $0(0.00)$ & $4(0.66)$ & $4(0.66)$ \\
\hline & $\mathrm{p}$ & 1.00 & 0.438 & 0.438 \\
\hline
\end{tabular}

variables of $\mathrm{HBV}$ infection, $\mathrm{HBV}$ infection among family was the independent risk factor for HBV infection among girls and boys, $p<0.01$, in addition to frequent injection among boys, $p<0.05$.

Table 4: Logistic regression analysis for predicting the risk factors for girl circumcision and for hepatitis B virus infection among both gender

\begin{tabular}{|c|c|c|c|c|}
\hline Dependent variable & Independent variables & AOR & $95 \% \mathrm{Cl}$ & $\mathrm{p}$-value \\
\hline \multirow{8}{*}{ Girl circumcision" } & Residence region & & & \\
\hline & Cairo & (B) & & \\
\hline & Upper Egypt & 3.4 & $2.4-4.8$ & $<0.001$ \\
\hline & Lower Egypt & 1.7 & $1.4-2.2$ & $<0.001$ \\
\hline & Mother education & & & \\
\hline & $\begin{array}{l}\text { Illiterate or read and } \\
\text { write }\end{array}$ & 6.2 & $3.4-11.5$ & $<0.001$ \\
\hline & Primary or preparatory & 1.9 & $1.3-2.8$ & 0.002 \\
\hline & Secondary or & ® & & \\
\hline \multicolumn{5}{|l|}{ HBV infection } \\
\hline $\begin{array}{l}\text { Infection among } \\
\text { girls }\end{array}$ & $\begin{array}{l}\text { HBV infection among } \\
\text { family }\end{array}$ & 104.7 & $26.2-418.9$ & $<0.001$ \\
\hline Infection among & Frequent injection & 15.2 & $1.4-170.8$ & 0.027 \\
\hline boys & $\begin{array}{l}\text { HBV infection among } \\
\text { family }\end{array}$ & 24.7 & $2.4-257.6$ & 0.007 \\
\hline
\end{tabular}

"Variables entered on step 1: Residence, mother education, father education, father occupation, mother occupation, socioeconomic status, "WVariables entered on step 1: Residence, blood transfusion, frequent Injection, hepatitis B infection among relative, history of surgery, age, circumcision.

AOR: Adjusted odds ratio, Cl: Confidence interval, HBV: Hepatitis B virus.

\section{Discussion}

While religious and cultural considerations are major reasons behind $\mathrm{MC}$, a growing volume of research shows the significant medical and public health benefits of this practice [3]. In the present study, the prevalence of $\mathrm{MC}$ was $(92.3 \%)$ which is similar to the prevalence reported in Syria $(92.8 \%)$ and Bangladesh (93.2\%). However, many Islamic countries reported higher values as in Afghanistan (99.8\%), Iran (99.7\%), Iraq (98.9), and Jordan (98.9\%) based on the number of people classified as Muslims and Jews [3]. On the other hand, much lower values were reported in Sudan $(39.4 \%)$ and South Sudan $(23.6 \%)$ which return to the different ethnic groups and different religions [1], [3]. The estimated global prevalence of $\mathrm{MC}$ ranged between 30 and $38 \%$ of these two thirds are Muslims [1], [3].

The results of this study revealed that the prevalence of MC was significantly higher in urban than rural areas (94.1\% vs. $90.1 \%$, respectively). Similar to our results, Lau et al. [17] reported higher prevalence in urban areas of 11 countries in Southeastern Africa while on the contrary, Tram and Bertrand [18] did not find any significant association. In Tanzania, the prevalence of MC among adolescents in rural areas was much lower $(17.3 \%)$ which may return to the different types of ethnic groups and different religions However, the prevalence increased up to $61.4 \%$ among Tanzanian Muslims [19].

The findings of the current study showed that the majority of MCs were performed by doctors and other healthcare team and more than $57 \%$ were done in private clinics, while barbers were the main providers for circumcision in Pakistan [20]. In Turkey, the majority of circumcision were done at home and by health technicians [21]. Non-medical personnel who perform circumcision as barbers and traditional healers most probably use unsterilized sharp equipment and use the same equipment (non-disposable) for many persons. This increases the probability of percutaneous transmission of bloodborne diseases as HBV and HCV infections.

The practice of FGM is deeply rooted in Egypt due social and cultural and may be religious background [22]. Despite that girl circumcision has been forbidden by law in Egypt, this practice has continued, especially in Upper Egypt and rural communities [6], [23]. There are many publications regarding FGM/C among women above age 15 years while few publications were reported among young girls in Egypt. Therefore, this study was concerned with analysis of data related to circumcision among young girls.

In the current study, $29.7 \%$ of girls were circumcised, a value which is lower than that reported before in Egypt (50.3\%) in 2008 by Tag-Eldin et al. [22]. However, it is slightly higher than the value $21.4 \%$ obtained from Demographic Health Survey (DHS) of Egypt in 2015 among girls aged from 0 to 19 years [23]. This may be attributed to the age distribution of the study sample which was skewed toward those in the age group above 10 years in 2008, while, in the DHS 2015, the reverse occurred. DHS 2015 survey documented that the percentage of girl circumcision was higher as 
the girls' age increased from $1.2 \%$ among girls $0-2$ years to $61.1 \%$ among girls aged $15-17$ years, and this was in accordance with the results of the current study, as prevalence ranged from $2.5 \%$ among girls aged $<5$ years to $50.5 \%$ among those in the age group 10-16 years. The prevalence of girl circumcision may be slightly decreased in the intervening years since declaration of SDGs. However, there is no reason to believe that data collected today would yield dramatically different results. UNICEF declared that "Egypt is not on track to reach the SDG target of eliminating FGM; compared to the rate of decline in the practice observed in the last 15 years, progress would need to be about 15 times faster to reach elimination by $2030 "(6)$. Based on DHS, the prevalence of FC in African countries showed marked variation being very low $(0.2 \%)$ in Benin while very high $(56 \%)$ in Gambia [5]. However, there was an overall decline in the prevalence of FC among young female adolescents [24].

After adjustment for independent variables associated with girl circumcision in bivariate analyses, low mother education and residence whether in Upper or Lower Egypt were the most significant risk factors for $\mathrm{FGM} / \mathrm{C}$. These findings are in agreement with the results published before in Egypt [22], [23], [25].

The percentage of $\mathrm{HbsAg}$ seropositivity was $0.12 \%$ among studied children, a value which was much lower than that reported in Turkey, Tanzania, and Bangladesh; 1.7\%, 2.1, and 2.4, respectively [26], [27], [28]. Moreover, the prevalence of positive anti-HBc was $0.42 \%$, which was also much lower compared to that reported from Turkey and Bangladesh with a total value of anti-HBc seropositivity of $5.4 \%$ in Turkey [26] and $16.3 \%$ in Bangladesh [28], denoting higher rate of exposure to HBV infection. The present study did not show any significant differences between circumcised and non-circumcised children as regards the different serological tests of $\mathrm{HB}$ viral infection, $\mathrm{HBsAg}$ positivity was $0.1 \%$ among circumcised and $0.15 \%$ among non-circumcised, anti-HBc positivity was $0.3 \%$ among circumcised and $0.53 \%$ among noncircumcised children, $p>0.05$. Even after stratifying the results according to gender, similar results of insignificant association between circumcision and HBV markers were found, $p>0.05$. Low prevalence of HBV markers among children point to the successful implementation of the program of immunization adopted in Egypt since 1992. Other studies stressed on the effectiveness of vaccination program in Egypt [16], [29]. Similar findings were reported by Ashraf et al. in Bangladesh [28] and Aziz et al. in Pakistan [20]. On the contrary, studies in Nigeria [30], [31] [32] found a significant association between history of circumcision and HBV transmission among children. Moreover, circumcision performed by barbers in Pakistan [33] and Turkey [21] was associated with $\mathrm{HBV}$ infection.

In the current study, more in depth analysis was done by stratification of data according to age groups to investigate the association between circumcision and hepatitis $B$ infection in different age groups. The results showed that the prevalence of HBV markers among circumcised and non-circumcised children in each age group were insignificant. According to urban and rural residence, stratified results showed that the prevalence of positive HBV markers among rural or urban circumcised and non-circumcised children were more or less similar. Further stratification of data according to the personnel performing the circumcision (doctors versus others) and place of circumcision (healthcare facility or private clinic versus home) showed again insignificant association between circumcision and HBV markers. This may return to the fact that most of the circumcisions were carried out at private clinics and healthcare facilities and were performed mainly by doctors where sterilized materials were used thus decreasing the likelihood of transmission of HBV infection. Moreover, in other studies, where children were circumcised by traditional non-medical providers, showed significant higher values of positive HBV markers than those circumcised by doctors and other medical staff [21], [33].

Ten children had positive anti-HBc and HBV DNA without HBsAg positivity indicates occult HBV infection. As regards the predicting variables of HBV infection, HBV infection among family was the independent risk factor for HBV infection among girls (AOR was 104.7, 95\% Cl 26.2-418.9) and boys (AOR was $24.7,95 \% \mathrm{Cl} 2.4-257.6), p<0.01$, in addition to frequent injection among boys (AOR was 15.2, 95\% $\mathrm{Cl}$ 1.4-170.8), $\mathrm{p}<0.05$. This finding indicates the importance of familial transmission of HBV in Egypt. Six out of the 14 infected children had positive family history of HBV and all of their infected families had only positive anti-HBc. HBV infection occurred despite of receiving $\mathrm{HBV}$ vaccination during infancy. This might be due to waning of HBV immunity among these children. This could be evident from our previous work, where among non-infected children, after giving a challenging dose of HBV vaccine to 1070 non seroprotective children, 103 $(9.6 \%)$ failed to generate anamnestic response (anti$\mathrm{HBs}<10 \mathrm{IU} / \mathrm{L}$ ), indicating absence immunity toward HBV infection [34]. Health promotion campaigns should be carried out to increase awareness of occult HBV infection, familial transmission of HBV infection, and the needed healthy familial habits.

It can be concluded that girl circumcision is still a problem especially among low-educated mothers and especially in Upper Egypt and rural areas. Child circumcision seems to play no role in HBV infection due to the minimal role of paramedical in performing circumcision and the successful immunization program adopted in Egypt. The findings of this study highlight the importance of using disposable syringes and health education program for prevention of intra-familial HBV transmission. 


\section{Limitation of the study}

The exact age of girl circumcision and shortterm complication of circumcision especially among girls is not available, in addition to the attitude of the girls toward this practice and whether they believe it is a religious or social habit.

\section{Acknowledgments}

They are also grateful to the children and their parents for their acceptance to participate in the project.

\section{References}

1. WHO-UNAIDS. Male Circumcision: Global Trends and Determinants of Prevalence, Safety and Acceptability; 2007. Available from: https://www.who.int/reproductivehealth/ publications/rtis/9789241596169/en. [Last accessed on 2020 Jan 25].

2. World Health Organization: Traditional Male Circumcision among Young People; 2009. Available from: https://www.who. int/maternal_child_adolescent/documents/9789241598910/en. [Last accessed on 2019 Dec 12].

3. Morris BJ, Wamai RG, Henebeng EB, Tobian AA, Klausner JD, Banerjee $\mathrm{J}$, et al. Estimation of country-specific and global prevalence of male circumcision. Popul Health Metr. 2016;14:4. https://doi.org/10.1186/s12963-016-0080-6 PMid:26933388

4. Modrek S, Liu JX. Exploration of pathways related to the decline in female circumcision in Egypt. BMC Public Health. 2013;13:921. https://doi.org/10.1186/1471-2458-13-921 PMid:24090097

5. Odukogbe AT, Afolabi BB, Bello OO, Adeyanju AS. Female genital mutilation/cutting in Africa. Transl Androl Urol. 2017;6(2):138-48. https://doi.org/10.21037/tau.2016.12.01 PMid:28540220

6. UNICEF. Female Genital Mutilation in Egypt: Recent Trends and Projections. FGM-Brochure-Recent-Trends-Projections-EgyptEnglish-2020; 2020. Available from: https://www.data.unicef. org/resources/female-genital-mutilation-in-egypt-recent-trendsand-projections. [Last accessed on 2020 Oct 09]. https://doi. org/10.31899/rh11.1045

7. Peltzer K, Kanta X, Banyini M. Evaluation of a safer male circumcision training programme for Ndebele traditional surgeons and nurses in Gauteng, South Africa: Using direct observation of circumcision procedures. Afr J Tradit Complement Altern Med. 2009;7(2):153-9. https://doi.org/10.4314/ajtcam. v7i2.50876

\section{PMid:21304627}

8. Brewer DD. Scarification and male circumcision associated with HIV infection in Mozambican children and youth. Webmed Cent Epidemiol. 2011;2(9):WMC002206.

9. Ayeni OA, Ayeni OO, Jackson R. Observations on the procedural aspects and health effects of scarification in subSaharan Africa. J Cutan Med Surg. 2007;11(6):217-21. https:// doi.org/10.2310/7750.2007.00026

\section{PMid: 18042335}

10. World Health Organization. Global Hepatitis Report, 2017. Geneva: World Health Organization; 2017. Available from: https://www.who.int/hepatitis/publications/globalhepatitisreport2017/en. [Last accessed on 2019 Jun 10].

11. World Health Organization. Hepatitis B Fact Sheet No. 204; 2020. Available from: https://www.who.int/en/news-room/factsheets/detail/hepatitis-b. [Last accessed on 2019 Aug 23].

12. Spearman CW, Afihene M, Ally R, Apica B, Awuku $Y$, Cunha L, et al. Hepatitis B in sub-Saharan Africa: Strategies to achieve the 2030 elimination targets. Lancet Gastroenterol Hepatol. 2017;2(12):900-9. https://doi.org/10.1016/ s2468-1253(17)30295-9 PMid:29132759

13. Mousa $\mathrm{H}$. Transmission of blood borne infections by circumcision procedure. J Infect Dis Ther. 2015;3(3):e107.

14. Sami SM, Salama II, Abdel-Latif GA, El Etreby LA, Metwally AI, Abd El Haliem NF. Hepatitis B seroprotection and the response to a challenging dose among vaccinated children in red sea governorate. Open Access Maced J Med Sci. 2016;4(2):219-25. https://doi.org/10.3889/oamjms.2016.043 PMid:27335590

15. Fahmy SI, El-Sherbiny AF. Determining simple parameters for social classifications for health research. Bull High Inst Public Health. 1983;13(5):95-107.

16. Salama II, Sami SM, Said ZN, Salama SI, Rabah TM, AbdelLatif GA, et al. Early and long term anamnestic response to HBV booster dose among fully vaccinated Egyptian children during infancy. Vaccine. 2018;36:2005-11. https://doi.org/10.1016/j. vaccine.2018.02.103 PMid:29530634

17. Lau FK, Jayakumar S, Sgaier SK. Understanding the socio-economic and sexual behavioural correlates of male circumcision across eleven voluntary medical male circumcision priority countries in Southeastern Africa. BMC Public Health. 2015;15:813. https://doi.org/10.1186/s12889-015-2135-1

18. Tram $\mathrm{KH}$, Bertrand JT. Correlates of male circumcision in Eastern and Southern African countries: Establishing a baseline prior to VMMC scale-up. PLoS One. 2014;9(6):e100775. https:// doi.org/10.1371/journal.pone. 0100775 PMid:24955963

19. Weiss HA, PlummerML, Changalucha J, Mshana G, ShigongoZS Todd $\mathrm{J}$, et al. Circumcision among adolescent boys in rural Northwestern Tanzania. Trop Med Int Health. 2008;13(8):105461. https://doi.org/10.1111/j.1365-3156.2008.02107.x PMid:18564352

20. Aziz S, Khanani R, Noorulain, W, Rajper J. Frequency of hepatitis Band $C$ in rural and peri urban Sindh. J Pak Med Assoc. 2010;60(10):853-7.

PMid:21381619

21. Tosun S, Balik I, Inan N, Saltoğlu N, Ormeci N, Sencan I, et al. The relationship between the methods of male circumcision procedures used in the past and the prevalence of viral hepatitis. Viral Hepat J. 2016;22(1):6-9. https://doi.org/10.4274/ vhd.65487

22. Tag-Eldin MA, Gadallah MA, Al-Tayeb MN, Abdel-Aty M, Mansour E, Sallem M. Prevalence of female genital cutting among Egyptian girls. Bull World Health Organ. 2008;86:269-74. https://doi.org/10.2471/blt.07.042093

23. Egypt Health Issues Survey, Ministry of Health and Population, Cairo, Egypt. El-Zanaty and Associates, Cairo, Egypt. Rockville, Maryland, USA: The DHS Program, ICF International; 2015. Available from: https://www.dhsprogram.com/pubs/pdf/fr313/ fr313.pdf. [Last accessed on 2019 Sep 15].

24. UNICEF, FEMALE Genital Mutilation/Cutting: A Global Concern; 
2016. p. 1-2. Available from: https://www.unicef.org/media/files/ fgmc_2016_brochure_final_unicef_spread.pdf. [Last accessed on 2019 Jun 19].

25. El-Zanaty F, Way A. Egypt Demographic and Health Survey 2008. Cairo, Egypt: Ministry of Health, El-Zanaty and Associates, and Macro International; 2009. Available from: https://www. dhsprogram.com/pubs/pdf/fr220/fr220.pdf. [Last accessed on 2019 Nov 22].

26. Otkun M, Erdogan MS, Tatman-Otkun M, Akata F. Exposure time to hepatitis $B$ virus and associated risk factors among children in Edirne, Turkey. Epidemiol Infect. 2005;133(3):50916. https://doi.org/10.1017/s0950268805003675 PMid: 15962558

27. Muro FJ, Fiorillo SP, Sakasaka P, Odhiambo C, Reddy EA, Cunningham CK, et al. Seroprevalence of hepatitis B and C viruses among children in Kilimanjaro region, Tanzania. J Pediatric Infect Dis Soc. 2013;2(4):320-6. https://doi. org/10.1093/jpids/pit018 PMid:24363930

28. Ashraf $\mathrm{H}$, Alam NH, Rothermundt $\mathrm{C}$, Brooks $\mathrm{A}$, Bardhan $\mathrm{P}$, Hossain $L$, et al. Prevalence and risk factors of hepatitis $B$ and $C$ virus infections in an impoverished urban community in Dhaka, Bangladesh. BMC Infect Dis. 2010;10:208. https://doi. org/10.1186/1471-2334-10-208

PMid:20630111

29. Afifi SS, Mahran MH, Said ZN, Salama II, El Khayat H. Serum level of anti-hepatitis $B$ surface antigen among newborns and fully vaccinated infants and children aged 6 to 11 years. Aust $J$
Basic Appl Sci. 2009;3(4):3239-45.

30. Agbede OO, Iseniyi JO, Kolawole MO, Ojuawo A. Risk factors and seroprevalence of hepatitis $B$ surface antigenemia in mothers and their preschool age children in Ilorin, Nigeria. Therapy. 2007;4(1):67-72. https://doi.org/10.2217/14750708.4.1.67

31. Olayinka AT, Oyemakinde A, Balogun MS, Ajudua A, Nguku P, Aderinola $\mathrm{M}$, et al. Seroprevalence of hepatitis B infection in Nigeria: A national survey. Am J Trop Med Hyg. 2016;95(4):9027. https://doi.org/10.4269/ajtmh.15-0874

PMid:27527630

32. Eke CB, Ogbodo SO, Ukoha OM, Ibekwe RC, Asinobi IN, Ikefuna AN, et al. Seroprevalence and risk factors of hepatitis $B$ virus infection among adolescents in Enugu, Nigeria. J Trop Pediatr. 2015;61(6):407-13. https://doi.org/10.1093/tropej/ fmv035

PMid:26411561

33. Seerat I, Mushtaq H, Rafiq M, Nadir A. Frequency and associated risk factors of hepatitis $B$ virus and hepatitis $C$ virus infections in children at a hepatitis prevention and treatment clinic in Lahore, Pakistan. Cureus. 2020;12(5):e7926. https://doi.org/10.7759/ cureus.7926

PMid:32494536

34. Salama II, Sami SM, Salama SI, Rabah TM, El Etreby LA, Hamid AT, et al. Immune response to second vaccination series of hepatitis $B$ virus among booster dose non-responders. Vaccine. 2016;34(16):1904-8. https://doi.org/10.1016/j. vaccine.2016.02.050

PMid:26930367 